\title{
Meme kanseri cerrahisi geçiren kadınların beden imajı ve cinsel uyumları
}

\author{
The self image and sexual adaptation of women undering breast \\ cancer surgery
}

Seçil Taylan, Nurcan Kolaç²®

\section{öz}

AMAÇ: $\mathrm{Bu}$ araştırmanın amacı meme kanseri cerrahisi geçiren kadınların beden imajı ve cinsel uyumlarını belirlemektir.

GEREÇ ve YÖNTEMLER: Araştırma tanımlayıcı türdedir. Araştırmanın evrenini mastektomi ameliyatı geçirmiș kadınlar olușturdu. Araștırmanın örneklemini İstanbul ilinde iki büyük hastanenin onkoloji polikliniğinde 01.12.2020-25.02.2021 tarihlerinde rutin kontrollerine devam eden meme cerrahisi geçirmiş meme kanseri olan 221 kadın oluşturmuştur. Evreni belli olan örneklem hesaplama yöntemi kullanılarak \%95 güven aralığında örneklem sayısı 141 olarak belirlenmiştir. Araştırmanın verileri, Tanıtıcı Bilgi Formu, Cinsel Uyum ve Beden İmajı Skalası kullanılarak elde edilmiştir. Verilerin değerlendirilmesinde tanımlayıcı istatistiksel yöntemler grupların karşılaştırılmasında Mann-Whitney U testi, tanılama davranışları için yordayıcıları lojistik regresyon analizi kullandı. BULGULAR: Kadınların yaş ortalamasının $43.25 \pm 16.83 \% 79.4$ ünün kanser tanılama süresinin 1-5 yıl olduğu, \%58.1'ine cerrahi yöntem olarak lumbektomi yapıldığı, \%39.0'ının II. evre kanser olduğu saptandı. Beden İmajı ve cinsel uyum alt ölçeklerinin korelasyonu incelendiğinde sonraki beden imajı alt ölçekleri ile cinsel uyum ve memelerin cinsel önemi alt boyutu arasında pozitif, cinsel işlevsellik alt boyutu arasında negatif zayıf korelasyonel ilişki olduğu saptand. Meme kanseri sonrası eş ile sorun yaşama durumlarına göre Cinsel Uyum ve Beden İmajı Skalası ölçek alt boyutlarının tümünde istatistiksel olarak anlamlı bir fark olduğu belirlendi. Eş ile sorun yaşadıklarını algılayan kadınların eş ile sorun yaşamayan kadınlara göre sonraki beden imajı puanının 1,756 kat, cinsel uyum puanının meme kanseri korku puanının 1.113 kat ve memelerin cinsel önem puanının 3.156 kat arttığı belirlenmiştir. Sonuç: Çalışma sonucunda meme kanseri cerrahisi geçiren kadınlarda beden imajı ile cinsel uyum ve memelerin cinsel önemi arasında anlamlı fark olduğu eş ile sorun yaşayan kadınların beden imajı ve memelerin cinsel önem puanları arttığı belirlenmiştir. Hemşirelerin mastektomi sonrası kadınlara profesyonel boyutta psikososyal destek sağlamaları önerilir.

Anahtar Kelimeler: Meme kanseri, cerrahi, beden imajı, cinsel yaşam, hemşirelik
${ }^{7}$ Kumluca Sağlık Bilimleri Fakültesi, Hemsirelik Bölümü, Kumluca, Antalya, Türkiye ${ }^{2}$ Marmara Üniversitesi Sağlık Bilimleri Fakültesi, Hemşirelik Bölümü, Halk Sağlığı Hemşireliği Anabilim Dalı, İstanbul, Türkiye

\section{Yazışma Adresi/ Correspondence:}

Dr. Öğr. Üyesi Seçil Taylan

Akdeniz Üniversitesi, Kumluca Sağlık Bilimleri Fakültesi, Hemşirelik Bölümü, Kumluca 07350 Antalya, Türkiye

Tel: $\quad$ +905303462062

E-mail: taylansecil@gmail.com

\section{ABSTRACT}

OBJECTIVE: The aim of this study is to determine body image and sexual orientation after breast cancer surgery.

MATERIAL and METHODS: The sample of the descriptive study consisted of 221 women with breast cancer who had undergone breast surgery, who were continuing their routine controls in oncology outpatient clinics of two large hospitals in Istanbul, between 01.12.2020-25.02.2021. The sample calculation method with a known population is updated to 141 with $95 \%$ confidence. The Version of the Research, Descriptive Information Form, Sexual Harmony and Body Image Scale are obtained. In the evaluation of the data, descriptive methods, Mann-Whitney $U$ test for comparison of groups, predictor regression analysis was used for diagnostic logistics. RESULTS: The average age of women was $43.25 \pm 16.83$ years, $79.4 \%$ had cancer diagnosis period $1-5$ years, $58.1 \%$ had lumbectomy as a surgical method, $39.0 \%$ had II. stage cancer was determined. When the correlation between Body Image and sexual adjustment subscales was examined, it was found that there was a positive weak correlation between the subsequent body image subscales and the sexual adjustment and the sexual importance of breasts subscale, and a negative weak correlational relationship between the sexual functionality subscale. A statistically significant difference was found in all sub-dimensions of the Sexual Adjustment and Body Image Scale according to the situation of having problems with the spouse after breast cancer. It was determined that women who perceived that they had problems with their spouses had an increase of 1.756 times the next body image score, 1.113 times the breast cancer fear score of the sexual adjustment score, and the sexual importance score of the breasts 3.156 times compared to the women who did not have a problem with their spouse.

CONCLUSION: As a result of the study, it was determined that there is a significant difference between body image and sexual harmony and the sexual importance of breasts in women who have undergone breast cancer surgery. Nurses are recommended to provide professional psychosocial support to women after breast cancer surgery.

Keywords: Breast cancer, surgery, body image, sex life, nursing

\section{Gíriș}

Meme kanseri dünya genelinde en yaygın görülen kanser türü olarak küresel bir halk sağlığı sorunudur. Kadınlar arasında ölüme neden olan ikinci kanserdir ve her yıl yeni kanser vakalarının \%30'unu oluşturmaktadır. ${ }^{[1,2]}$ Türkiye'de, 100.000 kadında \%24.9-\%43.0 arasındadır ve Türk kadınlarında en sık görülen kanserdir. ${ }^{[3]}$ 
Meme kanserinde cerrahi yöntemler bir tedavi olma seçeneğini sunmakla birlikte kadının beden imajının bozulmasına, benlik saygının azalmasına neden olup kadınlık imajına zarar verebilir. Meme cerrahisi kadınlar için psikolojik açıdan en yıkıcı tedavilerden biri olarak kabul edilir. Başta beden imajı olmak üzere kadınları bir çok açıdan etkiler ve kanserin kendisinden daha fazla travmaya neden olabilir. ${ }^{[2,4,5]}$ Memelerin, kadınlığın ve cinselliğin belirgin sembolü olarak görülmesi, kanser tanısı nedeniyle cerrahi girişim yapıldığında kadının beden imajına, annelik, cinsellik, ve çekicilik duygularına karşı bir tehdit oluşturmaktadır. ${ }^{[1]}$ Konu ile ilgili olarak yapılan çalışmalarda, kadınlara uygulanan cerrahi uygulamaların kadınlarda doğurganlık, meme kaybı, kadınlık kaybı ve cinsellik özelliklerini yitirme gibi olumsuz duygulara neden olduğu bildirilmiştir. Özellikle memenin tamamının çıkarılması beden imajını, kadınlık duygularını ve cinselliklerini olumsuz etkilemektedir. Bunların yanı sıra, genel yaşam kalitesinin temel unsurlarından biri olarak kabul edilen cinsel yaşam kalitesi, beden imajı bozukluklarından etkilenebilir. ${ }^{[6,7]}$ Cerrahi tedavilerin yanı sıra, kemoterapi, radyoterapi ve buna bağlı oluşan ağrı, saç dökülmesi, cilt değişiklikleri de olumsuz beden imajının nedeni olabilmektedir. Literatürde meme kanseri cerrahisi geçiren kadınlarda beden imajının bozulması \%15-30 olarak belirtilmektedir. ${ }^{[3]}$ Olumsuz yönde etkilenen beden imajı beraberinde sosyal izolasyona depresyona ve eşle cinsel yaşamlarının bozulmasına neden olabilir. ${ }^{[4,8]}$ Sonuç olarak, meme cerrahisine maruz kalmış kadınların hem teşhis hem de tedavisi önemli sıkıntılara neden olabilir. Kadınlar, meme cerrahisi sonrası hareketlerde bozulma, üst ekstremitelerde lenfödem gibi fiziksel değişikliklerin yanı sıra vazo motor semptomlar, vajinal kuruluk ve cinsel işlev bozuklukları yaşayabilirler. ${ }^{[5,9]}$

Meme kanseri teşhisi konan kadınların cinsel yaşam kalitesi üzerine yapılan önceki çalışmalarda, \%60 ila\%70'e varan cinsel işlev bozukluğu oranları bulmuştur. ${ }^{[5,10]}$ Meme cerrahisi sonrası tüm kadınların hem beden imajı hem de cinsel yaşamlarına yönelik farkındalık önemlidir. Bu nedenle meme cerrahisi geçirmiş kadınlara hem sağllk kurumlarında hem de evde takip ve izlemlerinde danışmanlık verilmesi, endişelerinin paylaşılması önem taşımaktadır. Bu çalışma, meme kanseri cerrahisi geçiren kadınların beden imajlarını ve cinsel yaşamlarını belirlemek amacıyla yapılmıştır. $\mathrm{Bu}$ araştırmadan elde edilen sonuçlar hemşirelerin mastektomi sonrası bozulmuş vücut beden imajı ve cinsel yaşamalarına yönelik taburculuk öncesi -sonrası ve evde bakım hizmetleri kapsamında sunacağı bakımın planlanmasına katkıda bulunabilir.

\section{GEREÇ ve YÖNTEMLER}

$\mathrm{Bu}$ çalışma, meme kanseri cerrahisi geçiren kadınların cinsel yaşamlarını ve beden imajlarını değerlendirmek amacıyla yapılmıştır. Tanımlayıcı araştırmanın evrenini, İstanbul ilinde iki büyük hastanenin onkoloji polikliniğinde 01.12.2020-25.02.2021 tarihlerinde rutin kontrollerine devam eden meme cerrahisi geçirmiş meme kanseri olan 221 kadın oluşturmuştur. Evreni belli olan örneklem hesaplama yöntemi kullanılarak \%95 güven aralığında örneklem sayısı 141 olarak belirlenmiştir. 18 yaş ve üzeri, mastektomi / lumpektomi geçiren, 18 yaş ve üstü kadınlar, iletişim kurabilen, Türkçe konuşabilen, okuma yazma bilen, görme ve işitme engeli olmayan, başka bir kronik hastalığı olmayan ve araştırmayı katılmayı kabul eden kadınlar araştırmaya dâhil edilmiştir.

\section{Veri Toplama Araçları}

Araştırmanın verileri, Tanıtıcı Bilgi Formu, Cinsel Uyum ve Beden İmajı Skalası (The SABIS) kullanılarak elde edilmiştir.

\section{Tanıtıcı Bilgi Formu}

Araştırmacılar tarafından hazırlanan formda, bireylerin tanıtıcı özelliklerini sorgulayan sekiz soru (yaş, eğitim, medeni durum, çalışma durumu, ekonomik durumu, kanser tanılama süresi, kanser evreleme, ameliyat türü, bulunmaktadır. ${ }^{[1,6,9]}$

\section{Cinsel Uyum ve Beden İmajı Skalası}

Ölçek, Dalton ve arkadaşları tarafından ameliyat sonrası Meme kanserli kadınlarda beden imajı ve cinselliği değerlendirmek için geliştirilmiştir. ${ }^{[1]]}$ SABIS, Beden İmajı Ölçeği ve Cinsel Uyum Ölçeği olmak üzere iki ayrı ölçekten oluşmaktadır. Altı maddelik Beden İmajı Ölçeğinin, önceki beden imajı skoru ve sonraki beden imajı skoru olmak üzere iki alt ölçeği vardır. Bu alt ölçekler meme kanseri tanısı öncesi ve sonrası beden imajını ölçmektedir. Sekiz maddelik Cinsel Uyum Ölçeği ise cinsel uyum, cinsel işlevsellik ve memelerin cinsel önem skoru olmak üzere üç alt ölçeğe sahiptir. Ölçeğin toplam puanı yoktur. Düşük puan zayıf cinsel uyumu ve zayıf beden imajını gösterir. Ölçeğin Türkiye'de geçerlik ve güvenirliği Erol Ursavaş ve Karayurt (SABIS-Tr) tarafından oluşturulmuştur. ${ }^{[12]}$ Cronbach alfa değerleri cinsel uyum alt ölçekleri için $.86, .83$ ve .89 , beden imajı alt boyutları için .77 ve .81 'dir. Bu çalışmada, Cronbach alfa değerleri cinsel uyum alt ölçekleri için $.88, .89$ ve .82 öncesi, beden algısı alt ölçekleri için .91 ve .90 'dır. 


\section{Verilerin Toplanması}

Veriler onkoloji polikliniğine rutin kontrollere gelen hastalar ile yüz yüze görüşülerek sessiz bir odada toplanmıştır. Verilerin toplanması yaklaşık 20 dakika sürmüştür.

\section{Araștırma Etiği}

Araştırmaya başlamadan önce Fenerbahçe Üniversitesi Klinik Araştırmalar Etik Kurulu'ndan (26.11.2020, FBU 2020-30) onay ve araştırmanın yapıldığı kurumdan yazılı izin alınmıştır. Araştırmaya katılmayı kabul eden bireylerden bilgilendirilmiş onam alınmıştır.

\section{Verilerin Değerlendirilmesi}

Veriler SPSS 23 (Statiscal Package of Social Science) programı kullanılarak \%95'lik güven aralığında, anlamlılık $\mathrm{p}<0.05$ düzeyinde değerlendirilmiştir. Demografik veriler için betimsel testler, ölçeğin hesaplanmasında ise ortalama, güvenirliği ölçmek için Cronbach alfa katsayısı kullanılmıştır. Verilerin normal dağılıp dağılmadığını belirlemek için Kolmogrow-Smirnov testi uygulanmıştır. Verilerin değerlendirilmesinde tanımlayıcı istatistiksel yöntemler (frekans, yüzde, ortalama puan, standart sapma) ve grupların karşılaştırılmasında Mann-Whitney U testi kullanılmışıtır. Tanılama davranışlarının yordayıcıları lojistik regresyon analizi kullanılarak değerlendirilmiştir. Lojistik regresyonda en uygun modelin belirlenmesinde Hosmer-Lemeshow, olabilirlik değeri (-2 log likelihood (-2LL indeksi) ve bağımsız değişkenlerin varyansı açıklama yüzdeleri göz önünde bulundurulmuştur. Değişkenlerin hangilerinin modelde yer alacağına karar vermek amaciyla adımsal (stepwise) yöntemlerden ileri doğru (forward) seçim yöntemi kullanılmıştır

\section{Araștırmanın Sınırlılığı}

Araştırmada bazı sınırlamalar vardır. Bunlardan biri bilgiler kadınların öz bildirimleri toplanmıştır. Bir diğer sınırlama ise örneklem büyüklüğünün küçük olmasıdır. Bu araştırma için bir örneklem seçimi yapılmamıştır. Bu nedenle sonuçlar sadece bu hastalarla sınırlıdır.

\section{BULGULAR}

Çalışmada sosyo-demografik özellikleri incelendiğinde, kadınların yaş ortalamasının $43.25 \pm 16.83$ olduğu, \%66,6'sının 22-50 yaşlarında seksüel aktif dönemde olduğu, \%53.9'unun ilköğretim mezunu, \%87.2'sinin evli, \%85.1'inin çalışmadığı ve \%42.6'sının ekonomik durumlarını orta düzeyde algıladıkları, \%79.4’ünün kanser tanılama süresinin 1-5 yıl olduğu, \%58.1'ine cerrahi yöntem olarak lumbektomi yapıldığı, \%39.0'ının II. evre kanser olduğu saptandı (Tablo 1 ).

Hastaların alt ölçek puanları incelendiğinde önceki beden imajı al boyut puanı $10.28 \pm 3.22$, sonraki beden imaj1 boyut puanı $7.27 \pm 3.68$, cinsel uyum alt boyut puanı 6.78 \pm 3.02 , Cinsel İşlevsellik alt boyut puanı 3.20 \pm 2.3 , memelerin cinsel önemi alt boyut puanı $6.8 \pm 2.2$ olduğu saptandı (Tablo 2).

Tablo 1. Karekteristik özelliklerin dağılımı

\begin{tabular}{lccc}
\hline & & $n$ & $\%$ \\
\hline Yaş & 22-50 yaş & 94 & 66.6 \\
$43.25 \pm 16.83$ & 51-65 yaş & 47 & 33.4 \\
\hline Eğitim & Eğitimsiz & 16 & 11.3 \\
& Illköğretim & 76 & 53.9 \\
& Ortaöğretim & 24 & 17.0 \\
& Üniversite & 25 & 17.8 \\
\hline Evlilik durumu & Evli & 123 & 87.2 \\
& Bekar & 18 & 12.8 \\
\hline Çalışma Durumu & Yes & 21 & 14.9 \\
& No & 120 & 85.1 \\
\hline Ekonomik durumu & Kötü & 32 & 22.7 \\
& Orta & 60 & 42.6 \\
& İyi & 30 & 21.3 \\
& Çok iyi & 19 & 1.34 \\
\hline Kanser tanılama & 1-5 yı & 112 & 79.4 \\
süresi & 6-10 yıl & 24 & 17.0 \\
& 11 yıl ve üzeri & 5 & 3.6 \\
\hline Cerrahi tipi & Lumbektomi & 82 & 58.1 \\
& Radikal mastektomi & 59 & 41.9 \\
\hline Kanser evresi & I.Evre & 20 & 14.1 \\
& II.Evre & 55 & 39.0 \\
& III.Evre & 42 & 29.8 \\
& IV.Evre & 24 & 17.1 \\
\hline
\end{tabular}

Tablo 2. Ölçek alt boyut ortalamaları, Cronbach alfa, Alınabilecek Ölçek puanları

\begin{tabular}{lccc}
\hline Ölçek ve alt boyutları & & $\begin{array}{c}\text { Ort } \pm \text { SS } \\
\text { (min-max) }\end{array}$ & $\begin{array}{c}\text { Alınabilecek } \\
\text { Ölçek } \\
\text { puanları }\end{array}$ \\
\hline Beden İmajı & & & \\
Önceki Beden İmajı Skoru & .91 & $10.28 \pm 3.22(6-15)$ & $3-15$ \\
Sonraki Beden İmajı Skoru & .90 & $7.27 \pm 3.68(3-12)$ & $3-15$ \\
\hline Cinsel Uyum & & & \\
Cinsel Uyum & .88 & $6.78 \pm 3.02 .(2-8)$ & $2-10$ \\
Cinsel Işlevsellik & .89 & $-3.20 \pm 2.3(-5-+6)$ & $-8-+8$ \\
Memelerin Cinsel Önemi & .82 & $6.8 \pm 2.2(2-9)$ & $2-10$ \\
\hline
\end{tabular}

Beden İmajı ve cinsel uyum alt ölçeklerinin korelasyonu incelendiğinde sonraki beden imajı alt ölçekleri ile cinsel uyum ve memelerin cinsel önemi alt boyutu arasında pozitif, Cinsel işlevsellik alt boyutu arasında negatif zayıf korelasyonel ilişki olduğu saptandı (Tablo 3). 
Tablo 3. Beden İmajı ve cinsel uyum alt ölçeklerinin korelasyonu

\begin{tabular}{lcc}
\hline Cinsel Uyum & $\begin{array}{c}\text { Önceki } \\
\text { beden imajı }\end{array}$ & $\begin{array}{c}\text { Sonraki } \\
\text { beden imajı }\end{array}$ \\
& $\mathrm{r}=.364$ & $\mathrm{r}=.258$ \\
$\mathrm{p}=.001$ & $\mathrm{p}=.006$ \\
\hline Cinsel İslevsellik & $\mathrm{r}=-.252$ & $\mathrm{r}=-.268$ \\
& $\mathrm{p}=.002$ & $\mathrm{p}=.001$ \\
\hline Memelerin Cinsel Önemi & $\mathrm{r}=.267$ & $\mathrm{r}=.256$ \\
& $\mathrm{p}=.001$ & $\mathrm{p}=.002$ \\
\hline
\end{tabular}

Meme Kanseri sonrası eş ile sorun yaşama durumlarına göre SABIS alt ölçek puanları arasındaki farkın dağılımı incelendiğinde ölçek alt boyutlarının tümünde istatistiksel olarak anlamlı bir fark olduğu belirlendi (Tablo 4).

Tablo 4. Meme Kanseri sonrası eş ile sorun yaşama durumları ile ölçek alt boyutları arasındaki farkın değerlendirilmesi

\begin{tabular}{|c|c|c|c|}
\hline \multicolumn{2}{|c|}{ Ölçek Puanları } & \multicolumn{2}{|c|}{$\begin{array}{c}\text { Meme Kanseri sonrası } \\
\text { eş ile sorun yaşama } \\
\text { durumları }\end{array}$} \\
\hline & & $\begin{array}{l}\text { Hayır } \\
(n=72)\end{array}$ & Evet $(n=69)$ \\
\hline & & $\bar{X} \pm S S$ & $\bar{X} \pm S S$ \\
\hline \multirow{4}{*}{$\begin{array}{l}\text { Beden } \\
\text { imajı }\end{array}$} & Önceki beden imajı & $11.22 \pm 3.69$ & $9.39 \pm 2.60$ \\
\hline & $\begin{array}{c}M W-U \\
p\end{array}$ & \multicolumn{2}{|c|}{$\begin{array}{c}22268.500 \\
.000\end{array}$} \\
\hline & Sonraki Beden İmajı & $8.28 \pm 3.62$ & $6.68 \pm 3.02$ \\
\hline & $\begin{array}{c}\mathrm{MW}-\mathrm{U} \\
\mathrm{p}\end{array}$ & \multicolumn{2}{|c|}{$\begin{array}{c}35266.500 \\
.000\end{array}$} \\
\hline \multirow{7}{*}{$\begin{array}{l}\text { Cinsel } \\
\text { Uyum }\end{array}$} & Cinsel Uyum & $6.78 \pm 3.02$ & $4.72 \pm 3.12$ \\
\hline & $\begin{array}{c}\mathrm{MW}-\mathrm{U} \\
\mathrm{p}\end{array}$ & \multicolumn{2}{|c|}{$\begin{array}{c}48750.00 \\
.000\end{array}$} \\
\hline & Cinsel İşlevsellik & $-4.24 \pm 2.32$ & $-2.26 \pm 2.23$ \\
\hline & $\begin{array}{c}M W-U \\
p\end{array}$ & \multicolumn{2}{|c|}{$\begin{array}{c}33.720 .00 \\
.000\end{array}$} \\
\hline & Memelerin Cinsel Önemi & $3.16 \pm .91$ & $5.39 \pm 1.60$ \\
\hline & $\mathrm{MW}-\mathrm{U}$ & \multicolumn{2}{|c|}{24530.00} \\
\hline & $p$ & \multicolumn{2}{|c|}{.000} \\
\hline
\end{tabular}

Araştırmada meme kanseri sonrası eş ile sorun yaşama durumlarına göre ölçek alt boyutları regresyonel ilişkisinin yordaması lojistik regresyon analizi ile değerlendirilmiştir. En iyi model 3. adımda oluşmuştur (Tablo 5). Eş ile sorun yaşama yordayıcıları içinde önceki beden imajı ve cinsel işlevsellik alt ölçekleri yer almamış ve model dışında kalmıştır. Eş ile sorun yaşadıklarını algılayan kadınların eş ile sorun yaşamayan kadınlara göre sonraki beden imajı puanının 1,756 kat, cinsel uyum puanının 1.113 kat ve memelerin cinsel önem puanının 3.156 kat arttığ belirlenmiştir (Nagelkerke R2:0.651, Model: $\mathrm{x}^{2}=512,705 ; \mathrm{p}=0,00$ ).
Tablo 5. Meme kanseri cerrahisi sonrası eş ile sorun yaşama durumunun ölçek alt boyutları ile regresyonel ilişkisinin lojistik regresyon ile incelenmesi

\begin{tabular}{|c|c|c|c|c|c|c|c|}
\hline $\begin{array}{l}\text { Bağımsız } \\
\text { Değişkenler }\end{array}$ & b & $S H$ & Wald & $p$ & $O R$ & \multicolumn{2}{|c|}{$95 \% \mathrm{Cl}$} \\
\hline Sabit & 6.767 & .705 & 219.970 & .000 & .000 & - & - \\
\hline $\begin{array}{l}\text { Sonraki } \\
\text { Beden İmajı }\end{array}$ & .662 & .107 & 38.038 & .000 & 1.756 & 1.570 & 2.391 \\
\hline Cinsel Uyum & .070 & .014 & 26.548 & .000 & 1.113 & 1.044 & 1.102 \\
\hline $\begin{array}{l}\text { Memelerin } \\
\text { cinsel önemi }\end{array}$ & 1.185 & .092 & 165.564 & .000 & 3.156 & 2.730 & 3.916 \\
\hline
\end{tabular}

Forward Stepwise (Wald) yöntemi kullanıldı; en anlamlı model 3. Adımda oluştu. Nagelkerke R2:0.651. Model: $x^{2}=512.705 ; p=0.00 . .{ }^{*} p<0.05{ }^{* *} p<0.01$. OR: odds ratio. SH: Standart Hata.

\section{TARTIȘMA}

Meme kanseri, son yıllarda artan insidansı ile kronik bir hastalık olarak kabul edilmektedir. Meme kanserinde, gelişmiş tanı yöntemleri ve daha az agresif olan cerrahi tedaviler sayesinde hayatta kalma süresini uzamış ve yaşam kalitesi artmıştır. Meme kanseri olan hastaların yaklaşık \%61'i 5 yıl tanı konulduktan sonra hayatta kalacak ve dünya çapındaki hastaların yaklaşık\%50'si tanıdan sonra en az 15 yıl hayatta kalacaktır. ${ }^{[2]}$ Araştırmalar, meme kanserinden sonra bir kadının cinsel yaşamında özellikle cinsel uyarılmadaki bozulmalar da dahil olmak üzere bir dizi fiziksel değişikliği belirtmektedir. ${ }^{[2,13-16]}$ Bunlar kemoterapi sonrası kimyasal olarak tetiklenen menopoz ve meme kanseri cerrahisinden kaynaklanan yağlanma, orgazm, doğurganlık kaybı korkusu, olumsuz beden imajı, cinsel çekicilik, kadınlık kaybı, depresyon ve anksiyete gibi değişiklikleri içerir. ${ }^{[2,14]}$

Cinsel aktivite ve zevk, her yaştan yetişkin için yaşam kalitesinin önemli bileşenleri olarak kabul edilir. ${ }^{\left[{ }^{[0]}\right]} \mathrm{Bu}$ çalışmada kadınların çoğu (\%33.4) 51-65 yaş, arasında olup yaş ortalaması $43.25 \pm 16.83^{\prime}$ tür. Bu çalışmada kadınların çoğunun kimyasal olarak tetiklenen menopoz beraberinde kemoterapi ve meme kanseri cerrahisinden kaynaklanan, orgazm, cinsel, olumsuz beden imajı, kadınlık kaybı, depresyon ve anksiyetenin yanı sıra cinsel işlevsellik değişikliklerini kapsamış olabileceği düşünülmektedir. Bu çalışmada kadınların cinsel yaşamlarına ait problemlerin yaşları östrojen yoksunluğu nedeniyle daha yavaş ve daha yoğun hale gelen cinsel yanıtı (heyecan aşaması) etkilemiş olabilir. $\mathrm{Bu}$ yaşlarda orgazm fazı kısalabilir ve genital atrofi nedeniyle ağrı yaşanabilir. Benzer şekilde Uçar ve ark çalışmasında 50 yaş ve üzeri mastektomili kadınların eş uyumunun daha düşük olduğu belirlemiştir. ${ }^{[17]} \mathrm{Bu}$ nedenle meme cerrahisi geçiren kadınların mutlaka psikolojik olarak destek almaları gerekmektedir. 
Bir kadının estetik açıdan önemli gördüğü memeleri, sadece fizyolojik olarak bir rol oynamaz, aynı zamanda kadının, duygusallık ve cinselliğinin de bir sembolüdür. Bir kadın meme kanserinin tedavisi için mastektomi geçirdiğinde, vücut uyumunda bozulma yaşar ve bu kadının kendini kusurlu hissetmesine psikolojik olarak beden imajı ve cinsel uyumunun bozulmasına ve çeşitli sorunlara neden olur. ${ }^{[13,18-20]}$ Meme kanseri cerrahisi geçiren kadınların cinsel yaşamları ve beden imajlarını değerlendirmek amacıyla yapılan bu çalışmada meme cerrahisi geçiren kadınların olumsuz yönde etkilendiği belirlenmiştir. Bu konuda yapılan çalışmalar bu çalışmanın bulgularını destekler yöndedir. ${ }^{[1,6,9]}$ Kadınların cinselliğinin, meme kanserinden sonra özellikle karmaşık olabileceği, cinsel değişikliklerin çoğu zaman bir kadının hayatının en sorunlu yönü haline geldiği yaygın olarak kabul edilmektedir. Bu tür değişikliklerin etkisi başarılı tedaviden sonra yıllarca sürebilir ve ciddi fiziksel ve duygusal yönde etkilerle ilişkilendirilebilir. ${ }^{[7,19]}$

Kadınların görünümlerinde değişiklik yaşaması cinsellik ve beden imajında olumsuz duygular yaşamasına neden olur. ${ }^{[21]}$ Ayrıca, radyoterapi ve kilo alımı ile ilişkili cilt değişiklikleri, hormon veya kemoterapi gibi sistemik tedavilerin neden olduğu ağrı ve uyuşma gibi duyusal farklilıklar, olumsuz beden imajına katkıda bulunur. ${ }^{[7,16]} \mathrm{Bu}$ çalışmada meme cerrahisi yaşayan kadınlarda memenin cinsel işlevin önemli bir belirleyicisi olduğu görülmektedir. Bir kadının beden imajı, göğüslerinin sembolik anlamını ve önemini içerir. Göğüslerine ne kadar değer verirse, mastektomi olmanın yıkıcı etkilerini daha fazla yaşayabilir. Çalışmalarda kadınların bir veya iki memesinin alınması kadınlarda kadınlık kaybı, doğurganlık, cinsel işlevsellik ve eşle yaşanan problemlerle ilişkili olduğu bildirilmiştir. ${ }^{[7,15,16]} \mathrm{Bu}$ çalışmada kadınların beden imajı cinsel işlevsellik cinsel uyum ve memelerin cinsel önemi konusunda istatistiksel olarak anlamlı fark bulunmuştur. Bu durumdan dolayı kadınların mastektomi sonucunda vücut imajı ve cinsel işlevsellikleri ile ilgili endişeleri negatif beden imajı, kaçınılmaz olarak kadının ruh halini ve kişilerarası ilişkilerini etkileyebilir, sosyal damgalanmaya ve dolayısıyla sosyal izolasyona yol açabilir. Bu nedenle, bu çalışmada kadınların beden imajını olumsuz algılaması, potansiyel olarak birçok sağlık sorununu da belirleyicisi olarak görülebilir. Guedes ve ark. çalışmasında kadınların \%74.8'inde beden imajına ait sorunlar bildirmişlerdir. ${ }^{[5]}$ Kadınların kanser tedavisi ile birlikte bedensel sorunlarının devam edebileceği düşünülürse bu noktada uzun süre psikolojik ve bedensel sorunların azaltılması noktasında önemli girişimlere ihtiyaçları oldukları düşünülmektedir. Morone ve ark (2014) çalışmasında beden imajına yönelik kısa süreli takip ve rehabilitee edici müdahalenin etkiliği olduğunu bulmuştur. ${ }^{[20]}$

$\mathrm{Bu}$ çalışmada meme cerrahisi geçiren kadınların beden imajı algısı, memelerin cinsel önemi ve cinsel işlevsellik ve cinsel uyum arasında anlamlı ve aynı yönde bir ilişkinin bulunmuş olması kadınların beden imajı ile memelerin önemi ve cinsel uyuma ait problemlerin yüksek olduğunu göstermektedir. Oysa Uçar ve arkadaşlarının yaptığı çalışmada, beden algısı yüksek olan bireylerin, eşleri ile uyumlu oldukları sonucunu bulmuştur. Uçar'ın aynı çalışmasında beden imajı yüksek olan bireylerin eşle uyumunun da daha iyi olduğu belirlenmiştir. ${ }^{[17]}$ Sertöz ve ark. (2004)çalışmasında meme algısının benlik saygısının olumsuz yönde etkilediği kadınların cinsel işlev bozukluğu ve eşleri ile iletişimde bulunmaktan kaçındıkları bulunmuştur. ${ }^{[7]}$ Fobair ve ark. yaptığı çalışmada ise meme cerrahisi sonrası kadınlarda en büyük sorunun kemoterapiden kaynaklanan saç dökülmesi, kilo alma veya verme endişesi, daha düşük beden imaajı ve partnerin duygularını anlamadaki güçlügünün beden imajını etkilediğini belirtmektedir. ${ }^{[19]}$ Yan ve ark (2020) çalışmasında meme cerrahisi geçirmiş kadınların cinsel olarak yaşamlarından memnun olmadıklarını kendilerini daha az çekici bulduklarının ifade etmişlerdir. ${ }^{[22]}$ Aslında meme cerrahisi geçirenlerin cinsel problemleri isteksizliğinin çok yönlü ve karmaşık olduğu belirtilir. ${ }^{[23,24]} \mathrm{Bu}$ nedenle meme cerrahisi sonucu cinsellikle ilgili problemler konusunda kadınlara bilgilendirme yapılmasının hastalığa uyumu kolaylaştırabileceği ve psikososyal riskleri azaltabileceği düşünülmektedir. Meme cerrahisi sonucu memesini kaybeden kadınlarda cinsel işlevin değerlendirilmesi hasta takibinin önemli ve ayrılmaz bir parçası olması gerektiği konusunda diğer sağlık çalışanları ile iş birliği yapılması önem kazanmaktadır. ${ }^{[23,25]}$ Yan ve ark çalışmasında meme cerrahisi geçiren hastaların dörtte birinden daha fazlası aktif bir cinsel yaşamları olmad1ğını belirtmiştir. ${ }^{[22]}$ Meme kanserinin cinsel aktivite sıklığını azalttığını bildirmesine rağmen, hastaların sadece (\%10.9) tavsiye almak için bir doktorla gidip tartıştığını bulmuştur. ${ }^{[22]}$ Hemşirelerin eş -temelli girişimlere ağırlık vermesi ve eşlerin sorunlarını ifade etmesi ve uygun baş etme stratejileri geliştirmeleri için destek olması gerekmektedir Meme kanserinden kurtulanlar için cinsel sağlıkla ilgili farkındalığın artmasına rağmen, sağlık hizmeti sağlayıcıları cinsel sorunlarını ele alma konusunda pasiftir. Meme kanseri aynı zamanda bir çiftin hastalığıdır. Hemşireler çiftlerin cinsel sorunlarını iletişim kurarak çözebilir. Bu nedenle hemşirelerin hem birinci basamakta hem de klinikte çiftlere uygulayacağı uzu süreli programların etkili olabileceği düşünülmektedir. ${ }^{[26]}$ Nitekim 
yaptığ tartışıldığı programın cinsel yaşamı iyileştirmede etkili olduğu bulunmuştur. ${ }^{[26]} \mathrm{Bu}$ çalışmada beden İmajı ve cinsel uyum alt ölçeklerinin korelasyonu incelendiğinde sonraki beden imajı alt ölçekleri ile cinsel uyum ve memelerin cinsel önemi alt boyutu arasında pozitif, cinsel işlevsellik alt boyutu arasında negatif zayıf korelasyonel ilişki olduğu saptandı (Tablo 3). Yeterli cinsel işlev, genel yaşam kalitesi ve yaşam doyumunda önemli bir faktördür. İlişki kalitesi meme kanserli kadınlarda cinsel işlevin önemli bir belirleyicisi gibi görünmektedir ve fizyolojik uyarılma, ıslanma, orgazm ve doyum sürecini engelleyebilir.

\section{SONUÇ ve ÖNERILER}

Sonuç olarak meme cerrahisi sonarası özellikle kemoterapi tedavisi kadınlarda cinsel isteksizliğe eşle sorun yaşamasına neden olmuş ve beden imajına ait değişiklikler yaratmıştır. Normalde sağlıklı kadınlarda da fizyolojik olarak menopoza yol açan fizyolojik değişiklıkler yaşasa da bu değişikliklerin kademeli olarak 5 ila 10 yıl gibi uzun süre çiftleri cinsel olarak aktif bırakacağı cinsel işlevlerde, eş uyumunda daha az sorunla karşı karşıya bırakabileceği düşünülmektedir. Bu konudaki literatüre göre araştırmalar, meme cerrahisi geçiren hastaların tedaviden hemen sonra cinsel sorunlar yaşadığını göstermektedir. $\mathrm{Bu}$ çalışmanın sonuçlarına göre,

- Meme cerrahisi geçiren kadınların psikososyal gereksinimlerinin bütüncül bir yaklaşımla değerlendirilmesi ve bu doğrultuda kadınlara ve eşlerine bilgi vermeye özellikle duygusal ve sosyal desteklerini sunmaya çalışan hemşirelik girişimlerinin planlanması

- Daha büyük bir örneklemle ve ileriye dönük çalışmaların yapılması

- Kadınlara öz güvenlerini artırıcı eğitici materyaller ve endişelerini azaltan materyaller hazırlanabilir. Kadınların meme cerrahisi sonrası endişelerini azaltma, beden imajını ve yaşam kalitesini olumlu yönde artırmak amacıyla psikiyatri hemşireliği ve liyazon hemşireliği ile iş birliği kurulabilir.

- Meme cerrahisi geçiren kadınların eşlerine ameliyatlar, tedaviler ve sürecle başetme noktasında stratejiler geliştirilebilir.

- Meme cerrahisi geçiren kadınların multidisipliner bir ekip tarafından destek alınması, risk altında olanların tanımlanması ve onlara yönelik girişimlerin yapılması önerilir.
Etik Kurul Onayı

Çalışma, Fenerbahçe Üniversitesi Klinik Araştırmalar Etik Kurulu tarafından onaylandı. (onay tarihi ve sayısı: 26.11.2020/FBU 2020-30).

Hakem Değerlendirmesi

Dış bağımsız.

Çıkar Çatışması

Yazarlar çıkar ilişkisi olmadığını beyan etmişlerdir.

Finansal Destek

Herhangi bir mali destek alınmamışır.

\section{Ethics Committee Approval}

The study was approved by Fenerbahçe University Clinical Research Ethics Committee. (date and number of approval: 26.11.2020/FBU 2020-30).

Peer-review

Externally peer-reviewed.

Conflict of Interest

No conflict of interest was declared by the authors.

Financial Disclosure

No financial support has been received.

\section{KAYNAKLAR}

1. Archangelo SCV, Neto MS, Veiga DF, Garcia EB, Ferreira LM. Sexuality, depression and body image after breast reconstruction. Clinics (Sao Paulo) 2019;74:e883. [CrossRef]

2. Morales-Sánchez L, Luque-Ribelles V, Gil-Olarte P, Ruiz-González P, Guil R. Enhancing Self-Esteem and Body Image of Breast Cancer Women through Interventions: A Systematic Review. Int J Environ Res Public Health 2021;18:1640. [CrossRef]

3. Erturhan Türk K, Yılmaz M. The Effect on Quality of Life and Body Image of Mastectomy Among Breast Cancer Survivors. Eur J Breast Health 2018;14:205-10. [CrossRef]

4. Çalışkan Z. Erken Evre Meme Kanseri Kadınlarda Ameliyat Tercihleri ve Tercihleri Etkileyen Değişkenler. T. C. Ege Üniversitesi Sağlık Bilimleri Enstitüsü, Psikiyatri Ana Bilim Dalı, Yüksek Lisans Tezi, İzmir; 2007.

5. Rodrigues Guedes TS, Dantas de Oliveira NP, Holanda AM, Reis MA, da Silva CP, Rocha e Silva BL, et al. Body Image of Women Submitted to Breast Cancer Treatment. Asian Pac J Cancer Prev 2018;19:1487-93. [CrossRef]

6. Abrahams HJG, Gielissen MFM, Verhagen CAHHVM, Knoop $H$. The relationship of fatigue in breast cancer survivors with quality of life and factors to address in psychological interventions: A systematic review. Clin Psychol Rev 2018;63:1-11. [CrossRef]

7. Sertöz ÖÖ, Elbi Mete H, Noyan A, Alper M, Kapkaç M. Meme Kanserinde Ameliyat Tipinin Beden Algısı, Cinsel İşlevler, Benlik Saygısı ve Eş Uyumuna Etkileri: Kontrollü Bir Çalışma. Türk Psikiyatri Derg 2004;15:264-75. https://app.trdizin.gov. $\mathrm{tr} /$ makale/TIRRd01USXk/meme-kanserinde-ameliyat-tipininbeden-algisi-cinsel-islevler-benlik-saygisi-ve-es-uyumuna-etkilerikontrollu-bir-calisma

8. Karaöz B. Meme Kanserli Kadınların Üreme Sağlığı Konusundaki Gereksinimlerinin Belirlenmesi. T. C. Adnan Menderes Üniversitesi Sağlık Bilimleri Enstitüsü, Hemşirelik Ana Bilim Dalı, Yüksek Lisans Tezi, Aydın; 2008.

9. Boswell NE, Dizon SD. Breast cancer and sexual function. Transl Androl Urol 2015;4:160-8. [CrossRef]

10. Howes BH, Watson DI, Xu C, Fosh B, Canepa M, Dean NR. Quality of life following total mastectomy with and without reconstruction versus breast-conserving surgery for breast cancer: A case-controlled cohort study. J Plast Reconstr Aesthet Surg 2016;69:1184-91. [CrossRef]

11. Dalton, EJ., et al. Sexual Adjustment and Body Image Scale (SABIS): a new measure for breast cancer patients. Breast J, 2009;15:287-90. [CrossRef] 
12.Erol Ursavas, F., Karayurt Ö. Adaptation of the Sexual Adjustment and Body Image Scale in Turkish Breast Cancer Women. Int J Nurs Knowl. 2016;27:162-9. [CrossRef]

13. Ayaz A. Meme Kanserli Kadınlarda Beden İmajı ve Benlik Saygısı. T. C. Haliç Üniversitesi Sağlık Bilimleri Enstitüsü, Hemşirelik Ana Bilim Dalı, Yüksek Lisans Tezi, İstanbul; 2012.

14. Begovic-Juhant A, Chmielewski A, Iwuagwu S, Chapman LA. Impact of body image on depression and quality of life among women with breast cancer J Psychosoc Oncol 2012;30:446-60. [CrossRef]

15. Marino JL, Saunders CS, Hickey M. Sexual inactivity in partnered female cancer survivors. Maturitas 2017;105:89-94. [CrossRef]

16. Paterson CL, Lengacher CA, Donovan KA, Kip KE, Tofthagen CS. Body image in younger breast cancer survivors. Cancer Nurs 2016;39:E39-58. [CrossRef]

17. Uçar T, Uzun Ö. Meme kanserli kadınlarda mastektominin beden algısı, benlik saygısı ve eş uyumu üzerine etkisinin incelenmesi. Meme Sağlığı Derg 2008;4:162-8. https://app.trdizin.gov. $\mathrm{tr} / \mathrm{makale} / \mathrm{T} 0 \mathrm{RBMk} 5 \mathrm{ETXo} / \mathrm{meme-kanserli-kadinlarda-}$ mastektominin-beden-algisi-benlik-saygisi-ve-es-uyumu-uzerineetkisinin-incelenmesi

18. Boquiren VM, Esplen MJ, Wong J, Toner B, Warner E. Exploring the influence of gender-role socialization and objectified body consciousness on body image disturbance in breast cancer survivors. Psychooncology 2013;22:2177-85. [CrossRef]

19. Fobair P, Stewart SL, Chang S, D'Onofrio C, Banks PJ, Bloom JR. Body image and sexual problems in young women with breast cancer. Psychooncology 2006;15:579-94. [CrossRef]
20. Morone G, Iosa M, Fusco A, Scappaticci A, Alcuri MR, Saraceni VM. Effects of a multidisciplinary educational rehabilitative intervention in breast cancer survivors: The role of body image on quality of life outcomes. Sci World J 2014;2014:1-11. [CrossRef]

21. Gürler H, Yılmaz M. Meme Kanserli Kadınlarda Cerrahi Tedavi Sonrası Beden İmajı ve Cinsellik Arasındaki İlişki. Koç Üniversitesi Hemşirelikte Eğitim ve Araştırma Derg 2020;17:244-51. https:// avesis.cumhuriyet.edu.tr/yayin/ba835da8-cb0f-4195-864d$80 \mathrm{~d} 523 \mathrm{dbfd} 14 /$ meme-kanserli-kadinlarda-cerrahi-tedavi-sonrasibeden-imaji-ve-cinsellik-arasindaki-iliski

22. Yan R, Yu J, Tanimato T, Ozaki A, Lu X, Che B, et al. The relationship between sexual activity and sexual attitudes among breast cancer survivors in China Cancer Med 2020;9:3425-36. [CrossRef]

23. Erturhan Türk K. Meme Kanseri, Kadınlar ve Eşlerinin Yaşadığı Sorunlar. GÜSB D 2019;8:495-500. https://dergipark.org.tr/en/ download/article-file/913376

24. Pintado S. Self-concept and emotional well-being in patients with breast cancer. Rev Iberoam Psicol Salud 2017;8:76-84. [CrossRef]

25. Pacaric, S., et al. The quality of life of Croatian women after mastectomy: a cross-sectional single-center study. BMC Public Health, 2018;10;18:999. [CrossRef]

26. Jun E-Y, Kim S, Chang S-B, Oh K, Kang HS, Kang SS. The Effect of a sexual life reframing program on marital intimacy, body image, and sexual function among breast cancer survivors. Cancer Nurs 2015;34:142-9. [CrossRef] 